\title{
Can we still be Reformed? A reflection on the Reformed tradition and South Africa's modernity
}

\begin{abstract}
This article reflects on the potential of the Reformed tradition in the context of modernity in South Africa. This is of course a courageous venture: the meaning of the concepts "Reformed" and "modernity" are intensely debated and in some quarters even their usefulness is questioned. This is exactly why the argument presented in this article will not be much more than a tentative consideration. It will be done in three parts. The first part will examine challenges to being Reformed in South Africa. The second part investigates South Africa's modernity as a central challenge in more detail. The article concludes with a consideration of three impulses from the Reformed tradition that may prove helpful in the context of South Africa's modernity.
\end{abstract}

\section{CAN WE STILL BE REFORMED?}

The South African Reformed systematic theologian Dirkie Smit (cf. e.g. Smit 2003, Smit 2004 and even Smit 1998a) asks a provocative question: Can we still be Reformed? By "we" he clearly refers to those South African Christians who in some way or other are part of the Reformed tradition. And with "still" he alludes to the fact that such a question would have seemed virtually incomprehensible a few decades ago. South Africa's recent history, however, has brought tensions and challenges to the fore that merit a serious consideration of this question.

One of the most serious potential challenges to being Reformed in South Africa seems to be internal, namely Reformed theology itself (Smit 2003:237). Notions such as "the kingdom of God, ... covenant and federal theologies, ... theocratic ideals, ... claims to be a prophetic church and religion, ... [and] comprehensive philosophical worldviews" (Smit 2003:237) have at times been implemented as totalitarian political projects. In South Africa these notions played an important role in the Dutch Reformed Church's legitimation of apartheid. ${ }^{1}$

Ironically, Reformed theology - and possibly some of the very same notions mentioned above - also enabled many South African Christians to oppose apartheid. These Reformed Christians could denounce the unjust political system in prophetic terms and - later - declare a status confessionis in a classically Reformed manner (Smit 1984). But here a further irony presents itself: it seems as if the struggle years and Reformed theology employed did not prepare these Reformed Christians adequately for South Africa's radical modernisation (Smit 2003:239).

Also the continued problematic divisions between South African Reformed churches, a "remarkable affinity for schism and division, ... reluctance to become one, in spite of confessional heritage" evident in Reformed churches worldwide, might be caused by elements within the Reformed tradition itself (Smit 1992:92). Indeed, the Reformed primacy of God's sovereign and authoritative Word has often been translated to imply a rejection of "worldly" forms of authority, be they in the form of persons, meetings, documents - or structures (Smit 1998b:29).

Possibly the most significant (at least relatively) external challenge facing the Reformed

1 Smit (2004:3) reminds us that one could ask whether this theology was actually Reformed. 
tradition in South Africa is the "nature of the radical transformation that is still taking place", namely "the rapid institutionalisation of modernity" (Smit 2003:239). Profound political, economic and social changes - which took centuries to take place in Europe - were instituted virtually overnight in South Africa (cf. Smit 1996b:193ff). It is no wonder that some choose to speak of the country's "collapse into modernity" (Smit, following Beck and Giddens; cf. Smit 2008a:96).

It is on this challenge to being Reformed, namely the rapid institutionalisation of modernity, that the argument will be focused. The contested concept of "modernity" is consequently the subject of the second part this article's argument.

\section{WHICH MODERNITY?}

Defining modernity is notoriously difficult. It requires navigating through complex and entangled historical, philosophical, sociological, religious and legal narratives, and their multifaceted and diverse contemporary expressions. The complexity is exacerbated when the influence of European and American forms of modernity on African societies is taken into account. But for the all the complexity the evidence of modernity's influence in Africa is clear in enough. We are therefore obliged - in the face of great complexities - to at least attempt to conceptualise modernity in Africa, particular in its southernmost country. For the purposes of our argument two instruments are used to conceptualise modernity in South Africa: the phases that the debate on modernity in Africa have followed and methodologies that can be applied in understanding modernity.

\section{Phases and methodologies}

According to Probst, Deutsch and Schmidt (2002:4-11), the debate on modernity in Africa has had at least three phases. In the 1930s the experience of "fragmentation, fluidity and fusion" in Europe and the perception of the "decay, disintegration and dissolution" of Africa were understood as the fruits of modernity (Probst, Deutsch \& Schmidt 2002:4). Urbanisation, industrialisation, changed societal structures and the vague promise of progress were perceived as bringing fragmentation rather than new forms of social cohesion. In this first phase modernity was understood as contagion.

In the 1950s the first wave of democratisation started in Africa, which signalled a second phase in the debate on modernity in Africa. The - at least in theory - sovereign post-colonial nationstates were faced with new challenges, and processes of modernisation were understood as an appropriate reaction. Modernity was understood as a necessity for the new Africa - "inherently generic", leading all countries, "just as in late eighteenth-century Europe", to "equality and democracy" (Probst, Deutsch \& Schmidt 2002:9). But this optimism was to be short-lived.

Empirical research on the influence of modernity in Africa's sovereign states started to show that these states developed in unexpected and divergent ways. In this phase modernity was increasingly understood as contingency. This led a number of theorists to make use of the plural "modernities" rather than the singular "modernity". Of obvious importance in rendering the use of the plural analytically useful, the methodology used to conceptualise these modernities grew in importance. Knöbl (2002:168-72) identifies three dominant methodological approaches each with its own weaknesses and strengths - that may well aid us in conceptualising modernity as contingency also in South Africa.

It is possible, firstly, to define modernity in temporal terms. In such as scheme the Renaissance, Enlightenment, Reformation and revolutions in England, America and France typically play a central role. Once a historical sequence has been demarcated, it becomes possible work with 
modernity as such. However, finding consensus on such a sequence and its effects has proved to be rather difficult. Also tracing the developments of elements within these temporally-defined modernities may lead to disagreement on their very demarcations; as Knöbl puts it: "The terms 'modernity' or 'modern' cannot be separated from questions about the essence of an epoch called modernity" (Knöbl 2002:168).

A second framework that can be used to define modernity is by means of its defining cultural discourses. In such a scheme one typically finds concepts such as individualism, rationalism, progress, human rights and so forth. But such an approach runs the risk of being rather general. It is possible for these concepts to be translated into a too wide a variety of systems and institutions - to the extent that it may become difficult to understand what these systems and institutions have in common. Also consensus on the content and range of the concepts that constitute the cultural discourses may prove very difficult - although not impossible (Knöbl 2002:171).

A third possibility is to demarcate modernity by means of its institutions. Institutions, in this sense, are understood as those "collections of (broadly) agreed norms, rules, procedures, and routines - whether they are formally established and written down (in law or by decree) ... or whether they are informal understandings embedded in culture" (March \& Olsen in Leftwich 2005:140). Again, this methodology is not without its problems. Demarcating the range of institutions, understanding the connection between the intended and real function of the institutions, and dealing with the enduring connection between institutions, history and cultural discourses are not simple tasks. However, it may be that the advantages of such an approach outweigh its difficulties.

Perhaps the greatest advantage of an institutional interpretation of modernity is that it recognises the contingent nature of modernity and conceptually creates theoretical space for contextual particularities. This is closely connected to a second advantage: an institutional interpretation of modernity as contingency enables comparisons with, and making connections between, other modernities. Without undue generalisation, detecting supple connections and mutual influences seems to be possible. Indeed, it may even be possible to regard societies as modern in this sense when "they have responded to the institutional dynamics originating in the West, because they have founded and invented new institutions to counter or deal with the impact of the West" (Knöbl 2002:171). Lastly, theorists agree that the quality of a society's institutions have a direct influence on its economic, social and political development (cf. e.g. Smith 2005:163). For African societies this makes an institutional interpretation of modernity not simply something of theoretical interest, but holds the promise of also strengthening its development.

The argument of this article is based on the premise that, when considering the potential of the Reformed tradition within South Africa's modernity, it is helpful to interpret this modernity as a contingent phenomenon in terms of its institutions. For the purposes of this article the argument is limited to the consideration of three political institutions.

\section{CONSIDERING SOUTH AFRICAN MODERNITY}

Firstly, with the transition of 1994 - in particular by means of universal suffrage - democracy was established as an institution. This dramatic transition to democracy gave rise to continuing processes of democratic consolidation (cf. e.g. Southall 2003:55-61). Very specific factors influence this consolidation, notably policy capacity and poverty.

Regarding the country's policy capacity, especially its effective and efficient implementation influences South Africa's democratic consolidation (Taljaard 2005). The country shares difficulties with other young democracies such as retaining adequately qualified personnel, insufficient 
coordination, undue political influence, administrative inefficiency and the like (Smith 2005:165).

Poverty also influences South Africa's democratic consolidation. It leads to specific patterns of power - which has implications for the institutions of modernity. In Neeta Misra-Dexter and Judith February's words:

The general state of economic under-development that defines the reality of the majority of South Africans is ... [a] defining characteristic of South Africa's democracy. Citizens who struggle to gain access to employment, housing and transport, and suffer from ill-health, a lack of clean drinking water and inadequate education are limited in their political participation (Misra-Dexter \& February 2010:vii).

This institution of democracy can therefore be qualified: South Africa is a consolidating democracy amidst challenges such as improving the implementation of policy and the alleviation of poverty.

A second institution of South Africa's modernity relevant to our discussion is its constitutionalism. Again this institution needs to be qualified. The primacy of the South African Constitution - and its protection by the Constitutional Court - strongly asserts the secular nature of South Africa's democracy. It is secular in the original seventeenth-century sense: not dependent on religious forms of legitimacy. In addition to its secularity, the Constitution's Bill of Rights promotes and defends a robust and progressive form of pluralism. The Bill of Rights is regarded as a "cornerstone of democracy in South Africa" (Chapter 2, Article 7(1)) protecting the "full and equal enjoyment of all rights and freedoms" of all South Africans (Article 9(2)). This includes freedom of religion, belief and opinion (Article 15), freedom of expression (Article 16), freedom of association (Article 18) and the right to form and form part of cultural, religious and linguistic communities (Article 31). Despite enduring - albeit not legislated - divisions, South Africa's modernity is clearly meant to be characterised by robust interactions between equally free but different individuals and groups, leading to a constant repositioning of societal power relations (cf. Welker 2002:225-242, 2000:105ff).

Constitutionalism as institution in South Africa can therefore be described as secular constitutionalism aimed at promoting and protecting societal pluralism amidst continuing systemic and historical divisions.

A third political institution that characterises South African modernity is the ideal of a strong civil society. Public controversies regarding issues as diverse as media censorship ${ }^{2}$ and (earlier) the provision of antiretroviral treatment (Irin 2006) illustrate societal consensus on the importance of a strong civil society. But this institution also needs to be qualified, as civil society in African democracies functions in mostly post-colonial and often under-developed contexts with cultural expressions that differ markedly from those in Europe and the United States (Robinson and Friedman 2005:7).

In a recent overview of the state of civil society in South Africa, it is described as vigorous but shallow (Friedman 2010:121-4). Its vigour can be seen from the passionate and (often) competing perspectives that civil society organisations provide in response to decision-making in all three spheres of government. A close look to civil society in South Africa actually disproves the notion that civil society participation has been in decline after 1994 (Friedman 2010:1212). ${ }^{3}$ The challenge nonetheless remains to include more perspectives in the debate, perhaps by proactively creating more spaces for involvement. It is currently the case that organisations

2 A valuable source with newspaper articles on media censorship in South Africa can be found on the website of the Mail \& Guardian (see Bibliography).

3 In fact, Friedman alerts us to the fact that the anti-apartheid struggle cannot be classified as civil society activities, as civil society refers "to a particular dynamic that occurs when citizens' organisations use their right to a say in decisions to interact with democratic governments". There is "a clear difference between a civil society organisation operating within a democracy and a resistance movement trying to achieve a democracy" (Friedman 2010:123). 
within civil society seem mostly to react to decisions made by government, usually within the space perceived to be granted by decision-makers. Civil society is shallow in the sense that significant sections of the South African population simply do not enjoy access to it. It is accessible only to those who are in a position to organise themselves and who can articulate their interests in a way that might influence decision-making processes (Friedman 2010:123-4).

Civil society as political institution in South Africa can therefore be qualified by adding the challenges of the need to broaden the space available for participation and, and to deepen participation to include also those not in a position to participate.

Now that we have added some qualifications and raised some conceptual questions, the article will now conclude with a return to our initial question: can we still be Reformed - in context the South African modernity?

\section{BEING REFORMED}

The meaning of being Reformed is by no means simple to pin down. We will therefore not attempt to provide an exhaustive definition of the Reformed tradition in our consideration of being Reformed in the context of South Africa's modernity. The article concludes with some impulses suggested by Smit's own work on the Reformed tradition, as his self-descriptive perspective on the Reformed tradition may well guide us towards answering his initial question. ${ }^{4}$ We make use particularly of three impulses from his work.

The Reformed tradition is, firstly, embodied faith. The Reformed tradition has through the ages understood itself as more than a collection of ideas or dogmas - it is a concrete way of being in a specific historical and cultural environment, coram Deo (Smit 1998b:25). Sanctification as the embodiment of God's will as it is revealed through his Word is of paramount importance for the Reformed tradition (Smit 1998b:25). It is no surprise that this thrust towards an embodied faith is central when Smit chooses four Reformed convictions relevant for the Reformed tradition in South Africa (Smit 2008b). He constructs a narrative by connecting Reformed convictions confessed in four concrete situations: the conviction that "living unity, real reconciliation and compassionate justice should not be separated" in the Confession of Belhar; the conviction that "Reformed faith and order belong inseparably together" in the Church Order of the Uniting Reformed Church in Southern Africa; the conviction that "the Reformed faith opens our eyes to the suffering and the injustice of our world" in Kitwe; and the conviction that "our inadvertent omissions may contradict our words and our confessions, however Reformed they may sound" in Accra.

Such self-critical expressions of faith aimed at embodying unity, reconciliation and justice may well be some of the Böckenfördian presuppositions a liberal state cannot guarantee. ${ }^{5}$ Politics is not in a position to address the substantial challenge of formulating and implementing policy that can address extreme levels of poverty without the assistance of people and groups willing and able to embody their convictions. At the same time it can also be noted that politics is not in a position to create all the spaces and initiatives for the embodiment of faith.

This, of course, does not imply the approval of all policies of, or support for, a ruling party. Specifically people from the Reformed tradition are prone to be tempted to exchange the embodiment of convictions for a rootedness in a specific culture (Smit 1998a:14). This is one

4 It should be noted, though, that only some of his perspectives are chosen, and used as impulses for further reflection rather than a representation of his thought.

5 Cf. Ernst-Wolfgang Böckenförde's famous dictum: "The liberal and secular state lives from presuppositions it cannot provide" (Original German: "Der freiheitliche, säkularisierte Staat lebt von Voraussetzungen, die er selbst nicht garantieren kann”) (Böckenförde 1976:60). 
of the reasons why the Reformed conviction of a life coram Deo has always been focused by phrases and words such as loquendi (life before the speaking God) or ex audito Verbi (life before God borne from hearing God's words) (Smit 1998b:26). Reformed Christians remind themselves that they should embody their faith in a very specific God, who has chosen to reveal God self in very specific ways. ${ }^{6}$ The Reformed tradition is therefore, secondly, specifically Christian.

Put in other terms, it can be said that the gospel, and not the context, is the deepest reason for the Reformed emphasis on embodiment (cf. Smit 1994:83). This leads to the church having a unique identity. In Smit's words:

The Christian community of faith is not simply the religious variant of natural groups, movements, social strata and so forth. Their shared faith in Christ makes Christians part of the church, the body of Christ (Smit 1996a:125). ${ }^{7}$

Some might say that such an unashamedly Christian tradition would have difficulty in participating in a society with a secular constitution that promotes and protects its pluralisation. The theorist Wolfgang Huber reminds us, however, that such views are based on restricted understandings of secularisation in modern societies (cf. e.g. Huber 1999:42ff; Huber 2006). The secularisation of a society's constitution by no means implies the secularisation of society itself. In fact, it asks for engagement based a clear account of the sources that inform convictions.

Huber makes use of the concept "enlightened secularisation" to denote an understanding of secularism that forms the basis of a stable society where different religions can participate and cooperate. He describes the concept as follows:

"[T] he process of secularisation led to enlightened secularity, and from a Christian perspective enlightened secularity needs to be advocated and actively represented. This type of secularity is connected with the categorical distinction between the state and religion and respect for every person's dignity and the freedom of religion form its basis" (Huber 2005). ${ }^{8}$

Constructive public discourse is not served by vague and ambiguous religious content. The challenges lie in articulating religious convictions in a way that makes dialogue and cooperation possible.

A cursory look at some well-known Reformed theologians seems to show that the Reformed ecclesiology should make dialogue and cooperation especially possible for Reformed Christians. Calvin, Bavinck, Berkhof and Jonker, for example, all emphasised the catholicity of the Reformed ecclesiology (Smit 2002:128). In Smit's own theological writings and public and church participation he is unambiguous about this ecumenical and unifying thrust. In terms of our argument the Reformed tradition can therefore, thirdly, perhaps be described as collaborative. This focus on the catholicity of the church and indeed the universality of God's presence has through the ages provided Reformed Christians with the resources to collaborate amidst differences - often also with those who do not regard themselves as Christians.

6 Cf. e.g. Smit's focus on God's word in his explanation of what "Reformed" means to a synod of the Dutch Reformed Church: “[G]ereformeerdheid is .. 'n voortdurende luister na die Woord van God, die evangelie van die Drie-enige God, aan ons geopenbaar in Jesus Christus. Gereformeerdheid leef van die vreugdevolle hoor van die evangelie" (Smit 1999).

7 "Die Christelike geloofsgemeenskap is nie maar net die religieuse variant van natuurlike groepe, bewegings, sosiale strata en wat nog meer nie. Dit is hulle gemeenskaplike geloof in Christus wat Christene deel maak van die kerk, wat sy liggaam is."

8 "[D]er Prozess der Säkularisierung [hat] zu einer aufgeklärten Säkularität geführt, die man heute auch aus Gründen des christlichen Glaubens aktiv vertreten und verfechten muss. Denn diese aufgeklärte Säkularität und die mit ihr verbundene kategoriale Unterscheidung zwischen Staat und Religion hat sich als unumgängliche Voraussetzung für die Achtung der gleichen Würde jedes Menschen wie für die Wahrung der Religionsfreiheit erwiesen." 
In South Africa this ability to cooperate, to integrate the convictions of the other in shared visions is of course severely compromised. Although the Reformed tradition in South Africa is a "story of many stories" (Smit 1992), the disunity between Reformed churches seems to contradict the collaborative spirit of the Reformed tradition (Smit 2002).

In the context of South Africa's modernity it can nonetheless be said that the Reformed tradition still has the opportunity to contribute to both the deepening and the broadening of societal participation. Reformed churches, for example, are ideally positioned to deepen societal participation by advocating for the voiceless and by giving them the opportunity to articulate their concerns and to influence policy-making. This can possibly be done best by means of cooperation with groups - within and outside the church - who share the relevant concerns. But the legitimacy of Reformed churches' contribution will most likely depend on the measure and form of unity - or at least cooperation - between these churches.

\section{CAN WE STILL BE REFORMED?}

This contribution started with Dirkie Smit's provocative question" Can we still be Reformed?. We attempted to reflect on this question from the perspective of modernity in South Africa, specifically in terms of its political institutions. This tentative consideration suggests that it seems possible to still be Reformed in South Africa. Indeed, in terms of Dirkie Smit's reflections on the Reformed tradition, it seems as if we actually need to be Reformed.

\section{BIBLIOGRAPHY}

\section{The Constitution of South Africa.}

Böckenförde, E. 1976. Staat, Gesellschaft, Freiheit. Frankfurt a.M.: Suhrkamp.

Friedman, S. 2010. "Beneath the Surface: Civil Society and Democracy after Polokwane." In Misra-Dexter, N. \& February, J. (eds.) Testing Democracy: Which Way is South Africa Going? Johannesburg: Idasa, pp. 117-39.

Huber, W. 1999. Kirche in der Zeitenwende. Gesellschaftlicher Wandel und Erneuerung der Kirche.

Gütersloh: Verl. Bertelsmann Stiftung.

Huber, W. 2005. "Glauben in der Welt - Die Säkularisierung und Zukunft der Kirchen.” Online at http:// www.ekd.de/vortraege/huber/051022_huber_maulbronn.html. Accessed 10 January 2011.

Huber, W. 2006. "Gemeinschaft gestalten - Evangeliches Profil. Online at http://www.ekd.de/vortraege/ huber/060913_huber_geke_budapest.html. Accessed 10 January 2011.

Knöbl, W. 2002. "Modernization Theory, Modernization and African Modernities.” In Georg, J., Probst, P., Schmidt, H. (eds.) African Modernities. Oxford: James Currey, pp. 158-78.

Leftwich, A. 2005. "Theorizing the State.” In Burnell, P. \& Randall, V. (eds.) Politics in the Developing World. Oxford: Oxford University Press, pp. 139-54.

Leith, J. H. 1981. Introduction to the Reformed Tradition (revised edition). Atlanta, GA: John Knox Press.

Mail \& Guardian. "Media under Fire." Online at $h t t p: / / w w w . m g . c o . z a / s p e c i a l r e p o r t / m e d i a-u n d e r-f i r e$. Accessed 10 January 2011.

Misra-Dexter, N. \& February, J. 2010. “Introduction.” In Misra-Dexter, N. \& February, J. (eds.) Testing Democracy: Which Way is South Africa Going? Johannesburg: Idasa, pp. vii-xxiv.

Pearce, J. 2005. “Inequality.” In Burnell, P. \& Randall, V. (eds.) Politics in the Developing World. Oxford: Oxford University Press, pp. 59-73.

Probst, P., Deutsch, J. \& Schmidt, H. 2002. "Cherished Visions and Entangled Meanings.” In Georg, J., Probst, P., Schmidt, H. (eds.) African Modernities. Oxford: James Currey, pp. 1-17.

Robinson, M. \& Friedman, S. 2005. Civil Society, Democratisation and Foreign Aid in Africa. Brighton: Institute of Development Studies.

Smit, D. J. 1984. "Wat beteken status confessionis?" (What does status confessionis mean?). In Cloete, G. D. \& Smit, D. J. (eds.) 'n Oomblik van Waarheid. Opstelle Rondom die NG Sendingkerk se Afkondiging van ' $n$ Status Confessionis en die Opstel van 'n Konsepbelydenis (A Moment of Truth. Essays on the NG 
Sendingkerk's Announcement of a Status Confessionis and the Writing of a Concept Confession). Cape Town: Tafelberg, pp. 14-38.

Smit, D. J. 1992. "Reformed Theology in South Africa: A Story of Many Stories", Acta Theologica 12, (No. 1), pp. 88-110.

Smit, D. J. 1994. "Etiek na Babel? Vrae Rondom Moraliteit en die Openbare Gesprek in Suid-Afrika Vandag" (Ethics after Babel? Questions on Morality and Public Discourse in South Africa Today), Ned. Geref. Teologiese Tydskrif, (No. 1), pp. 82-92.

Smit, D. J. 1995a. "Etiese Spraakverwarring in Suid-Afrika Vandag" (Misunderstandings in Ethical Discourse in South Africa Today), Ned. Geref. Teologiese Tydskrif, (No. 1), pp. 87-98.

Smit, D. J. 1995b. "Het Suid-Afrika 'n Gemeenskaplike Morele Taal Nodig?" (Does South Africa Need a Shared Moral Language?), Hervormde Teologiese Studies 51, (No. 1), pp. 65-84.

Smit, D. J. 1995c. "Oor die Skepping van 'n Grammatika van Saamleef” (On the Creation of a Grammar of Living Together), Hervormde Teologiese Studies 51, (No. 1), pp. 85-107.

Smit, D. J. 1996a. "Oor die Kerk as Unieke Samelewingsverband (On the Uniqueness of the Church)", Tydskrif vir die Geesteswetenskappe 36, (No. 2), pp. 119-29.

Smit, D. J. 1996b. "Oor die Unieke Openbare Rol van die Kerk (On the Unique Public Role of the

Church)", Tydskrif vir die Geesteswetenskappe 36, (No. 3), pp. 190-204.

Smit, D. J. 1998a. "Vraagtekens oor Gereformeerde Integriteit? (Questions About Reformed Integrity)." In Boesak, W. A. \& Fourie, P. J. A. (eds.) Vraagtekens oor Gereformeerdheid (Questions About Being Reformed). Belhar: LUS Uitgewers, pp. 5-19.

Smit, D. J. 1998b. "Wat beteken 'Gereformeerd'? (What does 'Reformed' mean?).” In Boesak, W. A. \& Fourie, P. J. A. (eds.) Vraagtekens oor Gereformeerdheid (Questions About Being Reformed). Belhar: LUS Uitgewers, pp. 20-37.

Smit, D. J. 1999. "Gedagtes oor die NG Kerk en uitdagings vir die jare vorentoe." Speech delivered at the Dutch Reformed Church in Western and Southern Cape Regional Synod.

Smit, D. J. 2002. "“Christ Transforming Culture'? Nagedink oor die aard van die gereformeerde geloof" ("Christ transforming Culture"? Reflections on the Reformed faith"), Essentialia et Hodierna. Oblata PC Potgieter (Acta Theologica Supplementum), (No. 3), pp. 125-49.

Smit, D. J. 2003. "Can We Still Be Reformed? Questions From a South African Perspective.” In Alston, W. M. \& Welker, M. (eds.) Reformed Theology. Identity and Ecumenicity. Grand Rapids, MI: Wm. B. Eerdmans, pp. 233-53.

Smit, D. J. 2004. "On Adventures and Misfortunes - more stories about Reformed Theology in South Africa", Studies in Reformed Theology, (No. 9), pp. 208-35.

Smit, D. J. 2008a. "Mainline Protestantism in South Africa - and modernity? Tentative reflections for discussion", Ned. Geref. Teologiese Tydskrif 49, (No. 1 \& 2), pp. 92-105.

Smit, D. J. 2008b. "What does it mean to live in South Africa and to be Reformed?", Reformed World 58/4, pp. 265-83.

Smith, B. 2005. "State-building." In Politics in the Developing World. Oxford: Oxford University Press, pp. $155-70$.

Southall, R. 2003. Democracy in Africa: Moving Beyond a Difficult Legacy. Cape Town: HSRC Publishers.

Taljaard, R. 2005. "Building a Public Service That Can Deliver Change." In Misra-Dexter, N. \& February, J. (eds.) Testing Democracy: Which Way is South Africa Going? Johannesburg: Idasa, pp. 71-93.

Irin. 2006. "The Long Road to Aids Treatment." Online at http://www.mg.co.za/article/2006-11-08-thelong-road-to-aids-treatment. Accessed 10 January 2011.

Wagner, P. 2008. Modernity as Experience and Interpretation. Malden, MA: Polity Press.

Welker, M. 2000. Kirche im Pluralismus. Gütersloh: Kaiser Taschenbücher.

Welker, M. 2002. "Wovon der freiheitliche Staat lebt. Die Quellen politischer Loyalität im spätmodernen Pluralismus." In Reuter, H., Bedford-Strohm, H., Kuhlmann, H. and Lütcke, K (eds.) Freiheit verantworten. Festschrift für Wolfgang Huber zum 60. Geburtstag. Gütersloh: Kaiser, Gütersloher, pp. $225-42$. 


\section{KEYWORDS}

Modernity

South Africa

Reformed

DJ Smit

Contact details:

University of Pretoria

Private Bag X20

Hatfield, Pretoria, 0028

Email address: willem.fourie@up.ac.za 